\title{
The social drift of trees. Consequence for growth trend detection, stand dynamics, and silviculture
}

\author{
Hans Pretzsch ${ }^{1}$ (D)
}

Received: 15 September 2020 / Revised: 4 November 2020 / Accepted: 19 December 2020 / Published online: 12 February 2021

(c) The Author(s) 2021

\begin{abstract}
Recently, many studies worldwide tapped tree ring pattern for detection of growth events and trends caused by weather extremes and climate change. As long-term experiments with permanent survey of all trees are rare, growth trend analyses are mostly based on retrospective measurements of growth via increment coring or stem analyses of the remaining individual trees in older forest stands. However, the growth of the survivor trees in older stands may only unsufficiently represent the course of growth of the dominant trees throughout the stand development. Here, the more than 100 years survey data of the European beech (Fagus sylvatica L.) thinning experiment Fabrikschleichach in South Germany are used to show the longterm changes in social ranking of trees and their consequences for growth trend detection by retrospective tree ring analyses, for stand dynamics and silvicultural management. Firstly, a significant social upwards drift of initially medium-sized trees till 2010 is shown based on the trees' percentiles in the stem diameter distribution in 1904 versus 2010. The social climbing is stronger on the thinned compared to the unthinned plots. Secondly, we show that 40-60\% of the 100 tallest trees in 1904 were replaced by social climbers and down-ranked below the 100 tallest trees till 2010. Linear mixed model analyses reveal that the long-term trend of the diameter growth of the 100 dominant survivors in 2010 was on average by $23 \%$ steeper than the trend of the 100 tallest starters in 1904. This indicates that the survivors had a steeper and longer lasting growth than the originally dominant trees. Thirdly, the diameter growth trend in the last 20 years, from 1990 to 2010, is analyzed in dependency on the current and past social position. A linear model shows that early subdominance or suppression can significantly steepen the growth trend a century later and vice versa.

Finally, we discuss the implications of the social drift for the survivor-based growth trend analyses, for the stand dynamics, and silvicultural management.
\end{abstract}

Keywords Stem diameter growth trajectories · Increment coring · Social ranking · Survivor bias · Structural heterogeneity · Stand growth stability $\cdot$ Memory effect

Supplementary information The online version of this article (https:// doi.org/10.1007/s10342-020-01351-y)

Communicated by Peter Biber.

Hans Pretzsch

Hans.Pretzsch@tum.de

1 Chair for Forest Growth and Yield Science, TUM School of Life Sciences in Freising Weihenstephan, Technical University of Munich, Hans-Carl-von-Carlowitz-Platz 2, 85354 Freising, Germany

\section{Introduction}

Trees in seasonal forests record their autobiography in the annual ring width pattern. This autobiography can be harnessed for biomonitoring and bioindication (Markert et al. 2003). The annual or periodical stem growth is an integrative signal of a tree's growth and vitality (Dobbertin 2005). Growth rates primarily represent an unspecific tree response. However, given the impact of silvicultural measures, pathogen attacks, or environmental changes on response patterns, growth trajectories may both indicate and serve to quantify the effect of various external episodic or long-term disturbances of tree growth. Accordingly, a growing body of research worldwide is tapping tree ring chronology as an autobiographical measure to detect growth events and 
trends, e.g., caused by weather extremes and climate change (Borgaonkar et al. 2011; Camarero et al. 2018; Girardin et al. 2016; Pretzsch 2020a, b).

The detection of growth disturbances improves with continuity of measurement on long-term experimental plots, e.g., using repeated surveys or permanent dendrometer records (Nehrbass-Ahles et al. 2014; Prietzel et al. 2020; Spiecker et al. 2000). Thus, time series data should ideally be obtained over the entire tree lifetime of 100-200 years. However, such data are very rare (Nagel et al. 2012; Pretzsch et al. 2019). Instead, shorter measurement periods or retrospective measurements of growth via increment coring (Camarero et al. 2018; del Río et al. 2020; Pretzsch et al. 2020a and b, Spiecker et al. 2002) or stem analyses (Guttenberg 1915; Pretzsch 2020c; Spiecker et al. 2012; Wichmann 2001) of the remaining individual trees in older forest stands to trace back their growth as a substitute of permanent longterm survey are more common. This is a problem, because the growth of the survivor trees in older stands may not accurately represent the course of growth of the dominant trees throughout the stand development. Indeed, trees remaining in the advanced stand development phase may represent a characteristic latecomer's growth trajectory with low growth in the juvenile but accelerated growth in the adult development phase. Moreover, the growth trend of the survivors may not indicate any climate change induced growth trend but result from the natural social differentiation of the individuals within forest stands and represent the natural growth variation of a subset of latecomer trees (Brienen et al. 2017; Nehrbass-Ahles et al. 2014). Thus, using the surviving trees to make inferences about the long-term growth trend of the mean course of dominant trees, of all trees or the stand in total may be misleading.

The taller the initial tree size compared with neighbors (e.g., quantified by the diameter percentile), the better the primary individual growth potential and the perspective of a tree. Size growth is furthermore intrinsically determined by size (Bertalanffy von 1951; Zeide 1993). However, genetic determination, biotic and abiotic disturbances, and silvicultural treatment may further influence the development of the social position of individual trees, i.e., whether they maintain, improve or lose their relative social ranking that finally determines access to light and other resources. Many studies show that the tree size growth trajectory follows an S-shaped curve depending on age and size; and that quickstarters peak and decelerate earlier, while slow starting trees may accelerate in advanced ages (Guttenberg 1915; Martín-Benito et al. 2008; Smith et al. 2019). However, recent studies show that asymptotic bending of size growth occurs much later than assumed so far (Pretzsch 2020c, Sillett et al. 2015a and b, Stephenson et al. 2014). Nevertheless, initially smaller or suppressed trees in a stand may begin slower but continue to grow longer compared to taller trees of the same age (Assmann 1970; Magin 1959; Wenk et al. 1990).

Social differences between trees and social drift are caused by varying growth trajectories and result in structural heterogeneity. They may affect many ecological, economical and socio-economical forest functions and services such as habitat structure, wood quality, growth stability, recreation and protection functions against windthrow, erosion, or avalanches (Dieler et al. 2017; del Río et al. 2016). Moreover, social heterogeneity and drift over time may generate a continuous structural differentiation where late social climbers may replace the position of social 'losers' and thereby maintain a continuity of structure and function over time. This stands in juxtaposition to clone plantations, where the social ranking and variety of trajectories and timepoints of optimal harvest are kept very similar.

The question to which degree growth trend analyses based on the sampling of survivors are biased and systematically overestimated was raised among others by Cherubini et al. (1998) and Nehrbass-Ahles et al. (2014). The authors proposed sampling methods to reduce or avoid the bias. Brienen et al. (2017) further showed that tree demography can generally dominate growth trends inferred from tree ring analyses. Also, Duchesne et al. (2019) reported growth increases in boreal forests as artefacts stemming from sampling biases. Consequently, the study at hand aims to explain and quantify the survivor bias in monospecific and even-aged European beech (Fagus sylvatica L.) stands that are currently in the focus of growth trend analyses (Ammer et al. 2005; Bosela et al. 2016; Geßler et al. 2007; Pretzsch et al. 2020a, b; Rennenberg et al. 2004). Several studies reported a diameter growth increase in dominant trees by $30-40 \%$ in the last 100 years, which was mainly ascribed to the extension of the growing season, warming, increase in nitrogen deposition and the atmospheric $\mathrm{CO}_{2}$-concentration (Dulamsuren et al. 2017; Hilmers et al. 2019; Pretzsch et al. 2020c). In our study, those revealed growth trends will be contrasted with the magnitude of the potential survivor bias to avoid overestimation of growth trends derived from increment coring of mature dominating European beeches as practiced, i.e. as a substitute for bioindication and trend analyses where longterm experiments are lacking.

To examine this, we used data acquired from the approximately 200-year-old thinning experiment Fabrikschleichach 15 of European beech in South Germany, which contains unthinned (A-grade), and moderately (B-grade) and heavily (C-grade) thinned plots. We will employ these repeated surveys of the social status, growth, and tree morphology from 1904 to 2010 to analyze long-term changes in social ranking and respective growth trends.

First, we will address how social ranking (in terms of stem diameter percentiles) has changed from the first to the present survey ( $\sim 100$ years later) and how the collective of 
the 100 tallest trees changed over this time period. Second, the mean stem diameter growth of the 100 tallest trees in the beginning will be compared to the growth of the 100 tallest survivors at the end of the survey period. Third, we will examine how the growth trend of the survivors over the last 20 years has depended on their past and present social status. The questions were addressed for a 106-year period, for untreated, moderately, and heavily thinned stands, and additional crown measurements were used to characterize the morphological attributes of quickstarters compared with latecomers.

Specifically, we focused on the following hypotheses.

H1 There is a perfect correlation between the social ranking of trees at the beginning and end of the 106-year survey period, i.e., the ranking is stationary.

H2 There are no differences between the course of stem growth of the 100 tallest trees at the beginning and end of the survey period; i.e., there are no social climbers and losers within this dominant and co-dominant collective.

H3 The social ranking at the beginning of the 106-year survey period has no effect on the growth trend of the trees at the end of the survey period, i.e., the growth trend of the survivors is independent from their past social status.

Finally, we will discuss the implications of the social drift of trees in the context of growth trend analyses, forest stand dynamics, and silvicultural management.

\section{Material and methods}

\section{Material}

The long-term thinning experiment Fabrikschleichach 15 (FAB 15) in European beech was chosen for this study as it represents one of the longest continuously measured forest experimental plots worldwide. It is an ideal example for questioning methodological aspects of the above introduced growth trend analyses in European beech stands.

The about 0.4 ha sized unthinned, moderately thinned, and heavily thinned plots (A-, B-, and C-grade plots) of FAB 15 were established in $1870 / 1871$ in a 48 -year-old, even-aged European beech stand that originated from natural regeneration by shelterwood cutting (Burschel and Huss 1987 , p. 90-92) of a beech stand in 1822. Since their establishment, the plots have been measured 19 times. FAB 15 is located $1 \mathrm{~km}$ east of the village Fabrikschleichach and belongs to the Ecoregion 5.2 Steigerwald and to the forest enterprise Ebrach. The location is $10.62^{\circ} \mathrm{E}$ longitude and $49.95^{\circ} \mathrm{N}$ latitude, the elevation $470 \mathrm{~m}$ a.s.l., the annual precipitation $820 \mathrm{~mm}$ (420 $\mathrm{mm}$ in the growing season), the mean annual temperature $7.5{ }^{\circ} \mathrm{C}\left(14.5^{\circ} \mathrm{C}\right.$ in the growing season), and the length of the growing season 150 days. The natural vegetation in this region would be submontane European beech-sessile oak forests. Soils are mainly Loamic Luvisols according to Blume and Schad (2015) with Semionoten sandstone as basic material.

FAB 15 comprises A-, B-, and C-grade thinning plots. Most of the classic long-term experiments comprise socalled A-grade plots (VDFV 1902). "A-grade" is defined by VDFV $(1902, \S 4)$ as follows "This is limited to the removal of dying and dead trees, as well as any bowed pole wood. [...]. for the purpose of delivering material for comparative growth investigations only". In other words, on A-grade plots nothing more is done than closely monitoring natural mortality and removal of dying or dead trees to prevent possible stand damage coming from dead trees (infestations by fungi or insects). A grade-plots reveal the maximum stand density and self-thinning, and they serve as the reference for quantifying how different levels of stand density regulation effect productivity, carbon sinks and stand structure.

As B- and C-grade thinning moderately and heavily reduce stand density mainly by removing mainly small trees and only tall trees when they are of bad quality, they are called moderate and heavy thinning from below (VDFV 1902, § 4). The B- and C-grade plots were thinned 11 times since their establishment. The stand basal area of the remaining stands ranged between 28.6 and $58.4 \mathrm{~m}^{2} \mathrm{ha}^{-1}$ on the A-grade plot, 26.6 and $51.0 \mathrm{~m}^{2} \mathrm{ha}^{-1}$ on the B-grade plot, and 20.2 and $42.8 \mathrm{~m}^{2} \mathrm{ha}^{-1}$ on the $\mathrm{C}$-grade plot. This decrease in the stand basal area from the $\mathrm{A}$ - to the $\mathrm{C}$-grade plot reflects the increasing strength of thinning from below.

From the first survey at age 48 years in spring 1871 to the fifth survey at age 77 in autumn 1899, the tree measurements were registered in tally-sheets. The measurements included stem diameter at breast height, tree height, and height to crown base. In addition, the removal trees were recorded. In the course of the sixth survey in 1904 at a stand age of 82 years the trees were numbered individually. Since that time the individual tree development in terms of tree diameter, tree height and height to crown base is known and can be analyzed. This is the reason why the stand characteristics can be reported since 1871 and the individual tree characteristics not before 1904 .

The repeated measurements covered in addition to diameter at breast height $\left(d_{1.3}, \mathrm{~cm}\right)$ and tree height $(h, m)$, the height to crown base $(h c b, m)$ and at several surveys the crown radii of the trees in eight cardinal directions according to standards described by Pretzsch (2009, pp. 115-118). The eight radii were used to calculate the crown projection area 
Table 1 Stand characteristics of the A-, B-, and C-grade plots at the last survey in 2010 at the stand age of 188 years

\begin{tabular}{|c|c|c|c|c|c|c|c|c|c|c|c|}
\hline $\begin{array}{l}\text { Thin- } \\
\text { ning } \\
\text { grade }\end{array}$ & Stand age & $\mathrm{ha}^{-1}$ & $\mathrm{~cm}$ & $\mathrm{~m}$ & $\mathrm{~m}^{2} \mathrm{ha}^{-1}$ & $\mathrm{~m}^{3} \mathrm{ha}^{-1}$ & $\begin{array}{l}\text { Current annual } \\
\text { volume growth } \\
\mathrm{m}^{3} \mathrm{ha}^{-1} \mathrm{yr}^{-1}\end{array}$ & $\begin{array}{l}\text { Mean annual } \\
\text { volume growth } \\
\mathrm{m}^{3} \mathrm{ha}^{-1} \mathrm{yr}^{-1}\end{array}$ & $\begin{array}{l}\text { Removed } \\
\text { volume } \\
\mathrm{m}^{3} \mathrm{ha}^{-1}\end{array}$ & Intermediate yield & $\begin{array}{l}\text { Total } \\
\text { volume } \\
\text { yield } \\
\mathrm{m}^{3} \mathrm{ha}^{-1}\end{array}$ \\
\hline A & 188 & 381 & 44.1 & 36.1 & 58.4 & 1120 & 8.3 & 7.8 & 308 & 21.1 & 1460 \\
\hline B & 188 & 194 & 54.0 & 39.8 & 43.5 & 920 & 13.4 & 9.1 & 607 & 35.4 & 1715 \\
\hline $\mathrm{C}$ & 188 & 128 & 62.4 & 41.5 & 39.3 & 865 & 12.9 & 8.8 & 633 & 38.2 & 1655 \\
\hline
\end{tabular}

$\mathrm{N}$, tree number per hectare; $\mathrm{d}$ mean stem diameter; $\mathrm{h}$, mean tree height; BA stand basal area; Current annual volume growth, stand volume growth in terms of merchantable wood (> $7 \mathrm{~cm}$ at the smaller end) in the last survey period 2000-2010; Mean annual volume growth, average stand volume growth per year since stand establishment; Total yield, total stand volume growth since stand establishment; Removed volume, volume removed since stand establishment (dead trees on A-grade plot; thinned trees on B- and C-grade plots); Intermediate yield, removed stem volume/total yield $\times 100$. The Intermediate yield indicates how much of the total yield were already removed by preliminary harvest since stand establishment until age 188

in $\mathrm{m}^{2}\left(\mathrm{cpa}=\overline{\mathrm{cr}}^{2} \times\right.$ with $\left.\overline{\mathrm{cr}}^{2}=\sqrt{\left(r_{1}^{2}+r_{2}^{2}+\ldots+r_{8}^{2}\right) / 8}\right)$. The survey in 1981 included the measurement of the tree coordinates of all trees on the plots and the border trees outside the plots but with crowns reaching into the plots.

The repeated surveys resulted in the data suitable for calculation of all common stand characteristics for each of the 19 successive survey periods since 1870 (Biber 2013). Table 1 gives an overview of the stand characteristics at the last survey (see Pretzsch 2009, pp. 208-210 and Pretzsch 2019 , p. 309 for overview tables with all relevant stand characteristics). The reported stand level data were derived from the diameter and height records as well as from the removal trees. We used standard evaluation methods according to standard procedures recommended by DVFFA (1988). With the DESER-Norm (Johann 1993), the German Association of Forest Research Institutes, DVFFA, (in German: "Deutscher Verband Forstlicher Forschungsanstalten") has made an important step towards such a standardization. For estimating the merchantable tree volume of European beech, we used the approach by Franz et al (1973) with the equations and coefficients published by Pretzsch (2002, p. 170, Table 7.3).

The mean height at age 100 presented in Table 1 indicates a site index of I.-II. according to the yield of Schober (1967, 1975), with other words good-very good site quality and productivity. This is corroborated by the main stand characteristics of the three plots at the last survey (Table 1). The current annual volume growth in Table 1 refers to the last survey period from 2000 to 2010 . The mean annual volume growth, the total volume yield, the removed volume, and the intermediate yield in Table 1 refer to the stand development since its establishment in $1870 / 1871$. The stand density, represented by the tree numbers, $N$, stand basal area, BA and standing stem volume (merchantable wood $>7 \mathrm{~cm}$ at the smaller end), $V$, decreases continuously from the $\mathrm{A}$ - to the $\mathrm{C}$-grade due to the thinning interventions. This stand density reduction means more growing space for the remaining trees and had a strong positive effect on the stem diameter, $d$. The current and mean annual stand volume growth, and the total yield were increased by the thinning on the long term. The last two columns in Table 1 show that the removed volume since stand establishment is about double as high on the $\mathrm{C}$-grade compared with the removed volume on the A-grade plot (trees that were dead and dying due to self-thinning). The percentage of removed stand volume in relation to the total yield at age 188 were increased by the active thinning from 21.2 (A-grade) to $38.2 \%$ (C-grade).

Table 2 shows that the stem dimensions $d_{1.3}, h$, and $v$, at the last survey were much higher in moderately and heavily thinned stands than on A-grade plots. Even stronger was the effect of thinning on the crown dimensions, cr, cl, and cpa. The increased size on the B- and C-grade plots is associated with higher stem diameter and stem volume growth in the last survey period. Regarding all variables, the effect size
Table 2 Mean tree

characteristics of trees on the A-, B-, and C-grade plots at the last survey in 2010 at the stand age of 188 years

\begin{tabular}{lllllllll}
\hline Thinning & $\mathrm{d}_{1.3}$ & $\mathrm{~h}$ & $\mathrm{v}$ & $\mathrm{cr}$ & $\mathrm{cl}$ & $\mathrm{cpa}$ & $\begin{array}{l}\mathrm{id} \\
2000-2010 \\
\mathrm{~cm} \mathrm{yr}^{-1}\end{array}$ & $\begin{array}{l}\mathrm{iv} \\
2000-2010 \\
\mathrm{dm}^{3} \mathrm{yr}^{-1}\end{array}$ \\
\hline A-grade & $\mathrm{cm}$ & $\mathrm{m}$ & $\mathrm{m}^{3}$ & $\mathrm{~m}$ & $\mathrm{~m}$ & $\mathrm{~m}^{2}$ & 141 \\
B-grade & 52.7 & 35.8 & 2.68 & 2.88 & 15.14 & 27.38 & 0.11 & 320 \\
C-grade & 58.9 & 41.2 & 5.92 & 3.99 & 19.51 & 53.03 & 0.24 & 468 \\
\hline
\end{tabular}

The variable abbreviations are $d_{1.3}$, stem diameter at breast height; $h$, tree height; $v$, stem volume; cr, crown radius; cl, crown length; cpa, crown projection area; stem diameter increment; stem volume increment 
of thinning was much stronger for the transition from A- to B-grade than from B- to C-grade.

For more information about the long-term stand development of all three plots see Supplement Stand Description of FAB 15 in the Electronic Supplement. For more details about this long-term experiment see works by Assmann (1950, 1970) and Kennel (1972) regarding thinning reactions, by Franz et al. (1993) and Pretzsch et al. (2019) regarding long-term survey and monitoring and by (Pretzsch 1999, 2014a and b) dealing with growth trend analyses on FAB 15.

\section{Methods and models}

H1 There is a perfect correlation between the social ranking of trees at the beginning and end of the 106-year survey period.

For a descriptive view on the dependency between social position and tree growth, all individual tree diameter growth trajectories from 1904 to the last survey were modelled by straight lines ( $d=a_{0}+a_{1} \times$ age $)$ via linear regressions individually. The relationship $d$-age was represented by a linear model according to several recent studies on growth of European beech (Pretzsch et al. 2020a-c). Furthermore, based on the stem diameters of all trees of the first individual survey in 1904 the diameter percentiles (from $0=$ lowest to $100=$ predominant) were calculated. The plot of the slopes of the diameter growth courses over the percentile in 1904 allowed an overview of the nonlinear relationship between social position and course of tree growth for all three thinning grades.

In order to scrutinize any social drift with progressing stand development (H1), the stem diameter percentiles were also calculated for the last survey in 2010 . The linear regression

$\operatorname{perc}_{2010, \mathrm{k}}=a_{0}+a_{1} \times \operatorname{perc}_{1904, \mathrm{k}}+\varepsilon_{\mathrm{k}}$

was fitted to the stem diameter percentiles of the A-, B-, and $\mathrm{C}$-grade plots separately and also to the data of all three plots together. The resulting slopes $a_{1} \pm 3 t \mathrm{SE}$ indicated whether the slopes deviated significantly $(p<0.001)$ from a perfect concordance between the diameter ranking at the beginning and end of the survey period. For a strict scrutiny, we chose a 99.9\% confidence limits and corresponding tail probabilities of $p<0.001$. A stationarity of the slopes would be indicated by slopes of $a_{1}=1.0$.

H2 There are no differences between the course of stem growth of the 100 tallest trees at the beginning and end of the survey period.
In order to quantify the extent and effect of social drift, the 100 tallest trees per hectare in 1904 were compared with the 100 tallest in 2010 . The number of social climbers resulted as the number of trees that were among the 100 tallest in 2010 but not in 1904. This number was divided by 100 and provided the percentage of social 'climbers'. Analogously, the trees available among the 100 tallest in 1904 but no longer in 2010 provided the social 'losers'.

Furthermore, in order to compare the prospective and retrospective view on the collective of dominant trees the course of the diameter growth of the 100 trees that were the tallest at the beginning in 1904 (quickstarters) was compared with the course of the diameter growth of those trees that were the 100 tallest at the last survey in 2010 (latecomers, also called survivors in the following text). Throughout the following text we use the term quickstarters for trees that were among the 100 tallest trees at the beginning of the stand development. We will use the term latecomers or survivors for the trees that belonged to the 100 tallest trees at the end of the 188-year survey period. The growth trajectories of both quickstarters and latecomers were visualized and analyzed in detail.

In addition to their course of diameter growth the mean stem and crown characteristics of the four mentioned collectives, i.e., the quickstarters, survivors, climbers, losers were quantified and the attributes of the starters were tested (via $t$-test) against the climbers, the survivors against the losers.

In order to reveal any differences in their development, the collectives of the quickstarters and latecomers were analyzed by linear mixed effect models as follows. Models 2 and 3 were applied to analyze how the membership of a tree to the group of quickstarters (group 0) and latecomers (group 1) determined the intercept and slope of the stem diameter-tree age relationship. The fixed effect variables are tree age and group; latter is categorial with group $=0$ for the quickstarters and group $=1$ for the latecomers. The models in general can be seen as a typical linear relation between tree size in terms of stem diameter and group effects on both, the intercept and the slope. The fixed effects parameters are $a_{0}-a_{3}$. The indexes $i, j, k$ in the following equations refer to the levels of experimental plot, tree within plot, and single observation, respectively. The random effects $b_{\mathrm{i}}$ and $b_{\mathrm{ij}}$ cover the levels of plot and tree.

Model 2 was applied for the analyses at the A-, B-, and $\mathrm{C}$-grade plot levels separately. In this case the random effect variable $b_{\mathrm{i}}$ accounts for the temporal autocorrelation (several successive surveys) at the tree level

$d_{\mathrm{ik}}=a_{0}+a_{1} \times$ age $_{\mathrm{ik}}+a_{2} \times$ group $_{\mathrm{i}}+a_{3} \times \operatorname{age}_{\mathrm{ik}} \times \operatorname{group}_{\mathrm{i}}+b_{\mathrm{i}}+\varepsilon_{\mathrm{ik}}$

Model 3 was applied for the plot overarching analysis (pooled data of A-, B-, and C-grade). In this model, two random effect variables account for the hierarchical nature of 
the data. Random variable $b_{\mathrm{i}}$ accounts for the spatial correlation (several plots per experiment) between the plots and $b_{\mathrm{ij}}$ accounts for the temporal autocorrelation (several successive surveys) at the tree level.

$$
\begin{aligned}
d_{\mathrm{ijk}}= & a_{0}+a_{1} \times \operatorname{age}_{\mathrm{ijk}}+a_{2} \times \text { group }_{\mathrm{ij}} \\
& +a_{3} \times \operatorname{age}_{\mathrm{ijk}} \times \text { group }_{\mathrm{ij}}+b_{\mathrm{i}}+b_{\mathrm{ij}}+\varepsilon_{\mathrm{ijk}}
\end{aligned}
$$

The Models 2 and 3 were applied for stem diameter development of various tree groups depending on tree age, calendar year, and interaction between tree age and calendar year. In order to detect the respective growth behavior on the different plots first and derive a generalized growth pattern of the quickstarters and latecomers in a second step, I refrained from combining models 2 and 3 .

H3 The social ranking at the beginning of the 106-year survey period has no effect on the growth trend of the trees at the end of the survey period.

By Model 4 we analyzed any dependency of the current growth trend on the past and present social position of the tree. The model addressed the relationship between the slope of diameter growth in 1990-2010 and the diameter percentiles in 1904 and 2010 as follows.

slope $_{1990-2010, \mathrm{k}}=a_{0}+a_{1} \times \operatorname{perc}_{1904, \mathrm{k}}+a_{2} \times$ perc $_{2010, \mathrm{k}}+\varepsilon_{\mathrm{k}}$

In this model slope ${ }_{1990-2010}$ represents the mean annual diameter increase from 1990 to $2010{\mathrm{in} \mathrm{cm} \mathrm{yr}^{-1} \text { and perc }}_{1904}$ and perc $_{2010}$ reflect the diameter percentiles in 1904 and 2010 in \%. The time span 1990-2010 was chosen as it seems long enough to reflect any growth trend. The long temporal distance between 1904 and the period 1990-2010 is most interesting for analyzing any memory effects of past social positions of trees on their present growth.

The numbers of the Models 1-4 refer to the results in the text and in the captions of the tables.

The statistical software R 3.4.1 was used for all calculations, in particular the function lme from the package nlme (Pinheiro et al. 2018).

\section{Results}

\section{Overview of the stand and tree development}

The periodical annual stem volume increment, PAI, per hectare and year on the three plots, visualized on Fig. 1, shows the following relevant aspects for this study. Throughout the whole survey period the stand growth oscillates quite strongly but remains on a considerable high level. There is no clear decreasing age trend in the PAI development,

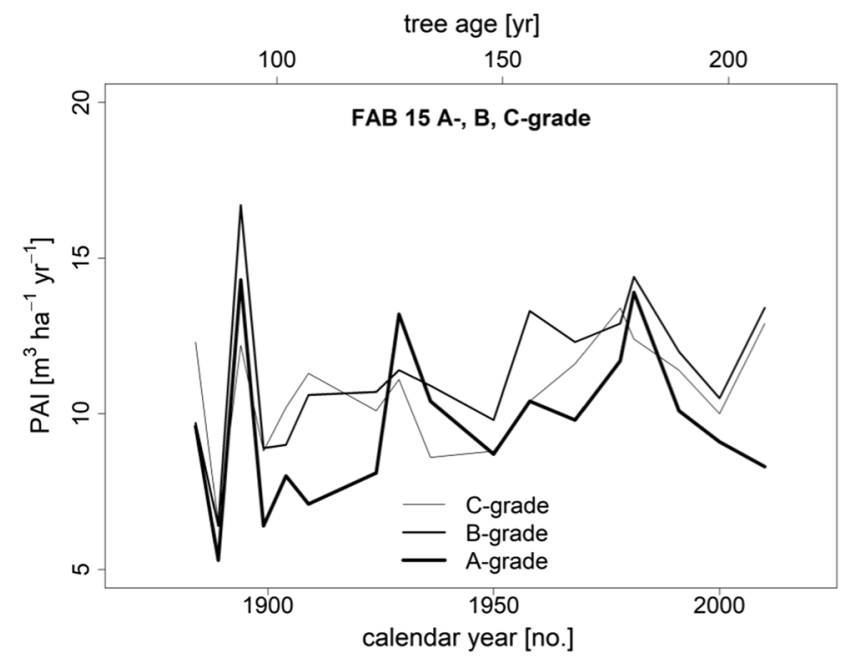

Fig. 1 Development of the periodical annual stem volume growth, PAI, on the A-, B-, and C-grade plots of the thinning trial in European beech Fabrikschleichach 15 shown from the establishment of the experiment in 1870 until present (age 48-188 years, see upper abscissa). A-grade, without thinning and only removal of dead or dying trees; B-grade, moderate thinning from below; C-grade, heavy thinning from below

although the stands were already 188 years old at the last survey. The PAI of the A-grade develops at the lowest level, the PAI on the B-, and C-grade plot is in most periods higher than on the A-grade. On the long term the thinning did not reduce the PAI and did not cause a preponed reduction or the PAI development over age.

The long continuation of stand growth, the high level beyond the age of 150 years and the high level of growth despite of the strong thinning indicate considerable positive deviations from the development predicted by the common yield tables for European beech by Schober $(1967,1975)$.

The courses of the stem diameter growth (Fig. 2a-c) are an essential basis for the subsequent analysis. The black trajectories represent the remaining trees in the stands; the red trajectories visualize the trees that dropped out by selfthinning on the A-grade plots and were removed by moderate and heavy thinning from below on the B- and C-grade plots. Comparison between the trajectories on the thinned and unthinned plots (Fig. $2 b$ and c versus a) evinces that thinning accelerated the diameter growth. The range of stem diameters at the last survey is about $20-70 \mathrm{~cm}$ on the A-grade and $40-90 \mathrm{~cm}$ on the C-grade plots. Interestingly, the courses of annual stem diameter growth show hardly any reduction although the trees aged to nearly 200 years till the end of the shown period 1904-2010 (Supplement Fig. 1). The courses are rather linear and intersect in many cases; i.e., the size ranking changed with progressing stand development. 

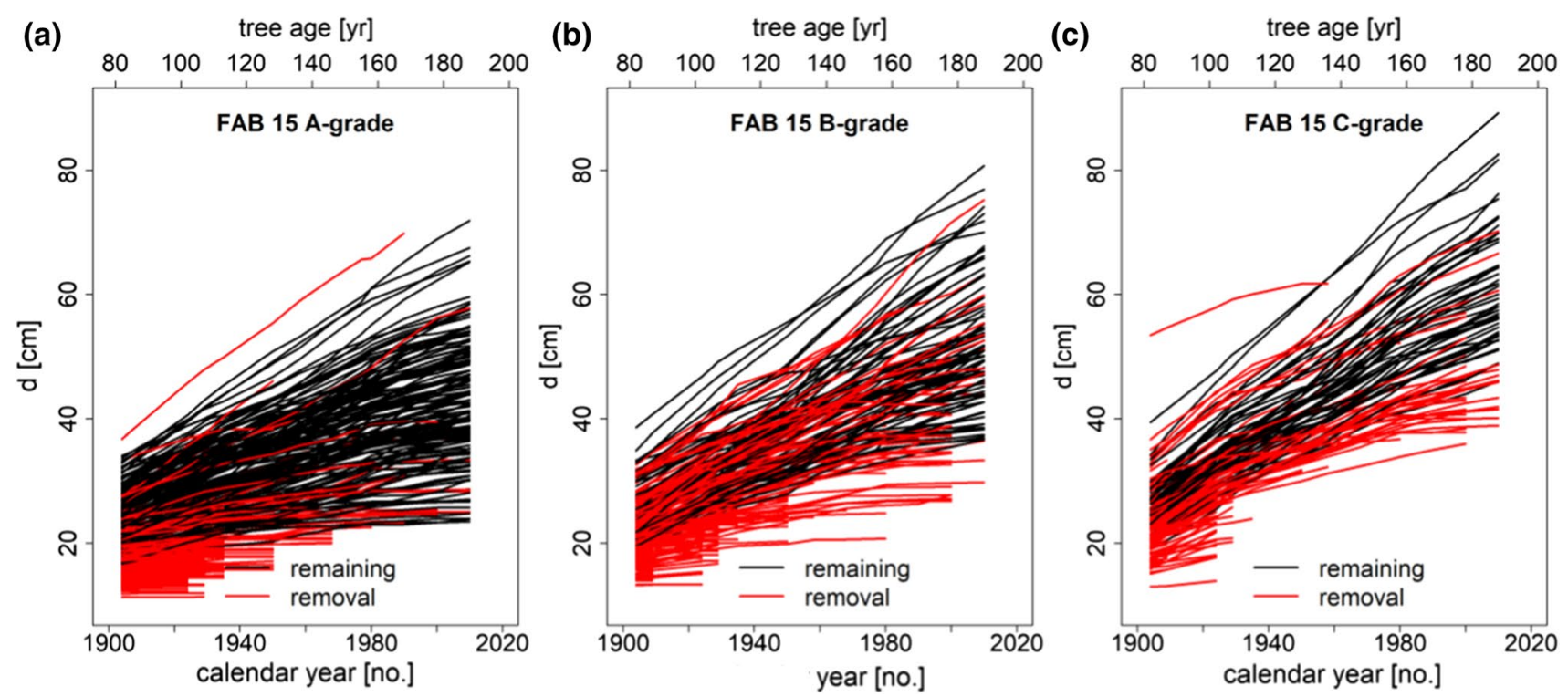

Fig. 2 Stem diameter growth of remaining (black) and removal (red) trees on the A-, B-, and C-grade plots of the thinning trial in European beech Fabrikschleichach 15 shown from 1904-2010 (age

82-188 years, see upper abscissa). A-grade, without thinning and only removal of dead or dying trees; B-grade, moderate thinning from below; C-grade, heavy thinning from below
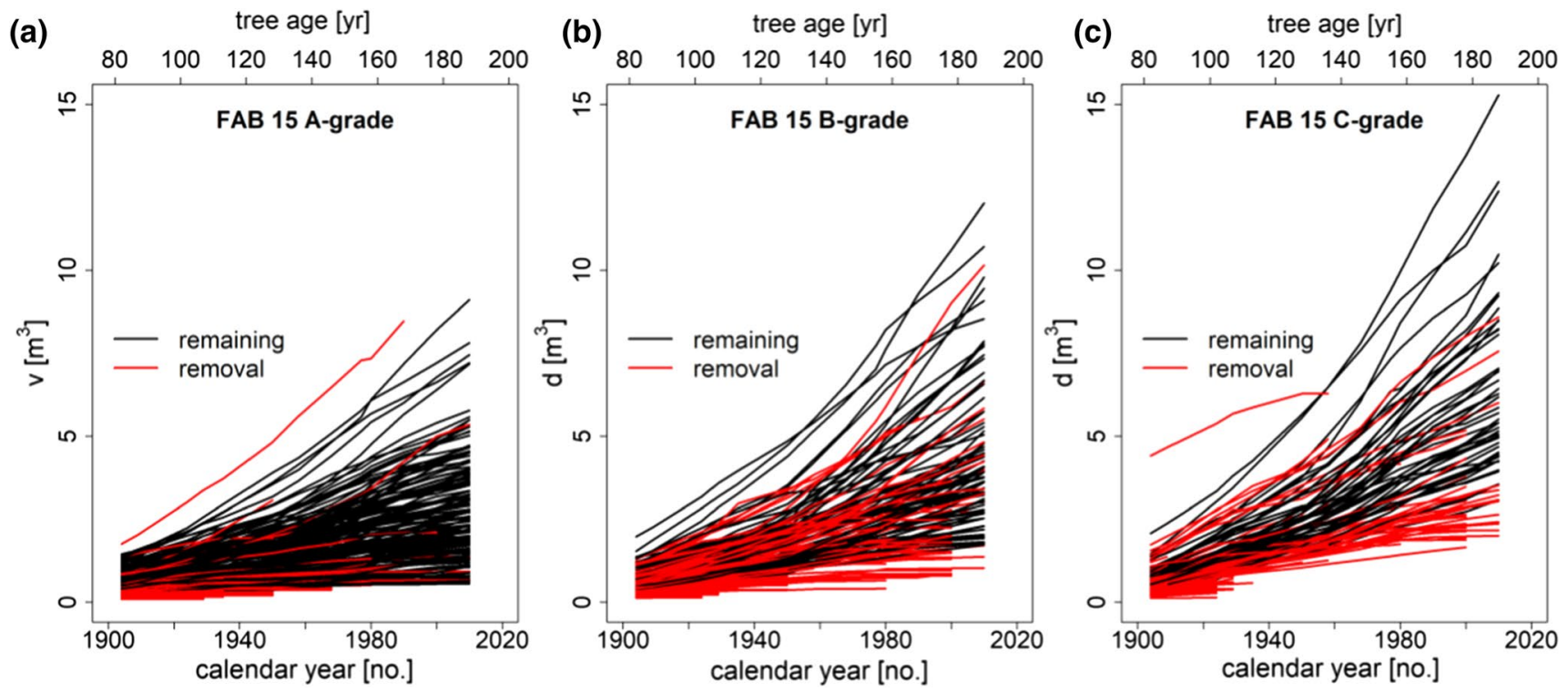

Fig. 3 Stem volume development of remaining (black) and removal (red) trees (merchantable volume $>7 \mathrm{~cm}$ at the smaller end) on the A-, B-, and C-grade plots of the thinning trial in European beech Fabrikschleichach 15 shown from 1904-2010 (age 82-188 years, see

The average trend is more or less linearly increasing in case of the diameter development (Fig. 2) and cubic in case of the stem volume development (Fig. 3). Interestingly, the linear trend of the stem diameter development and cubic trend of the stem volume proceeded from middle to advanced tree ages, and the trend is similar for all upper abscissa). For details about volume calculations see Sect. 2.1. A-grade, without thinning and only removal of dead or dying trees; B-grade, moderate thinning from below; C-grade, heavy thinning from below three thinning grades. The stem volume developments hardly showed any S-shaped trajectories (Fig. 3). This means that the annual individual trees' volume growth increased in most cases continuously until high tree ages (Supplement Fig. 2) and did not yet show a clear age-related reduction as assumed by textbooks by among others Kramer (1988, 
p. 66), Bruce and Schumacher (1950, p. 377), Wenk et al. (1990, p. 74), Assmann (1961, p. 80), or Mitscherlich (1970, p. 83).

The red trajectory above the rest of the trees in Figs. 2c and $3 \mathrm{c}$ (starting above the rest of the population and ending after the removal of the tree in the 1950ies) represents a hold-over tree from the previous stand generation. This tree was eliminated from the analysis.

\section{Correlations between the social ranking of the trees at the beginning and end of the 106-year survey period (H1)}

Figure 4 shows the individual trees' slopes $\left(\right.$ slope $=a_{1}$ ) of their diameter growth from 1904 to 2010 (based on fit by linear regression $d=a_{0}+a_{1} \times$ age) plotted over the trees' percentile at the first individual survey in 1904. These presented slopes come from individually fitted regression lines; so they do not include random effects. The small, subdominant trees with low percentiles in 1904 have low slopes of diameter growth and preferentially drop out during stand development on the A-grade plots (red dots, Fig. 4a). On the $\mathrm{B}$ - and C-grade plots the red dots represent the trees removed according to the guidelines for thinned from below; small trees removed due to their subdominant position and tall trees if of bad quality (VDFV 1902). On all plots the slopes of the diameter growth of the trees that survived until 2010 increased with their social position; i.e., in tendency taller trees have steeper courses of diameter growth.

Interestingly, all point clouds (Fig. 4a-c) widen with increasing percentile in 1904, i.e., trees with percentiles $>30 \%$ can both steeply or hardly grow in diameter. Despite their advantageous social positions, some trees show very shallow courses of growth (black points in the lower right edge), other trees show steep courses although they are only co-dominant or subdominant (black points in the upper layer in the middle). In summary this means that very low social position at the beginning mostly caused drop-out, however, with increasing social status the potential of social climbing as well as losing increases continuously.

Thinning generally increased the slope (level of the point clouds), the number of removal trees (red dots), and increased to some extent the probability of small trees to survive or even strongly climb (black points in the left lower edge in Fig. $4 \mathrm{~b}$ and c).

Figure 5 shows the percentiles 2010 plotted over the percentiles 1904 for the three thinning grades. Observations on the bisectoral line would indicate stationarity of the ranking. The black straight line shows the observed non-stationarity of the size ranking. In case of the A-grade the observed slope $( \pm \mathrm{SE})$ was $0.6807 \pm 0.0613$, this results in a $99 \%$ confidence interval $(p<0.001)$ of $0.4969-0.8645$ that does not include 1.0 and indicates a significant deviation from stationarity (Table 3). The respective values for the B-grade were 0.3600 \pm 0.1018 with an interval of $0.0546-0.6654$. The values for the C-grade were $0.5813 \pm 0.1088$ with an interval of $0.2549-0.9077$. The analogous analyses for the pooled data (A-, B-, C-grade combined) yielded $0.5653 \pm 0.0487$ with an interval of $0.4192-0.7114$ (Table 3 ). This means in all cases a highly significant $(p<0.001)$ deviation from stationarity, i.e., a high social drift.

All slopes $a_{1}$ were significantly $<1.0$, and indicate that subdominant trees in 1904 can often socially climb up, whereas dominant ones in 1904 can lose their privileged status. This tendency was stronger on the B-, and C-grade plots than on the A-grade. For more detailed statistical characteristics of the underlying regression and correlation see Table 3.
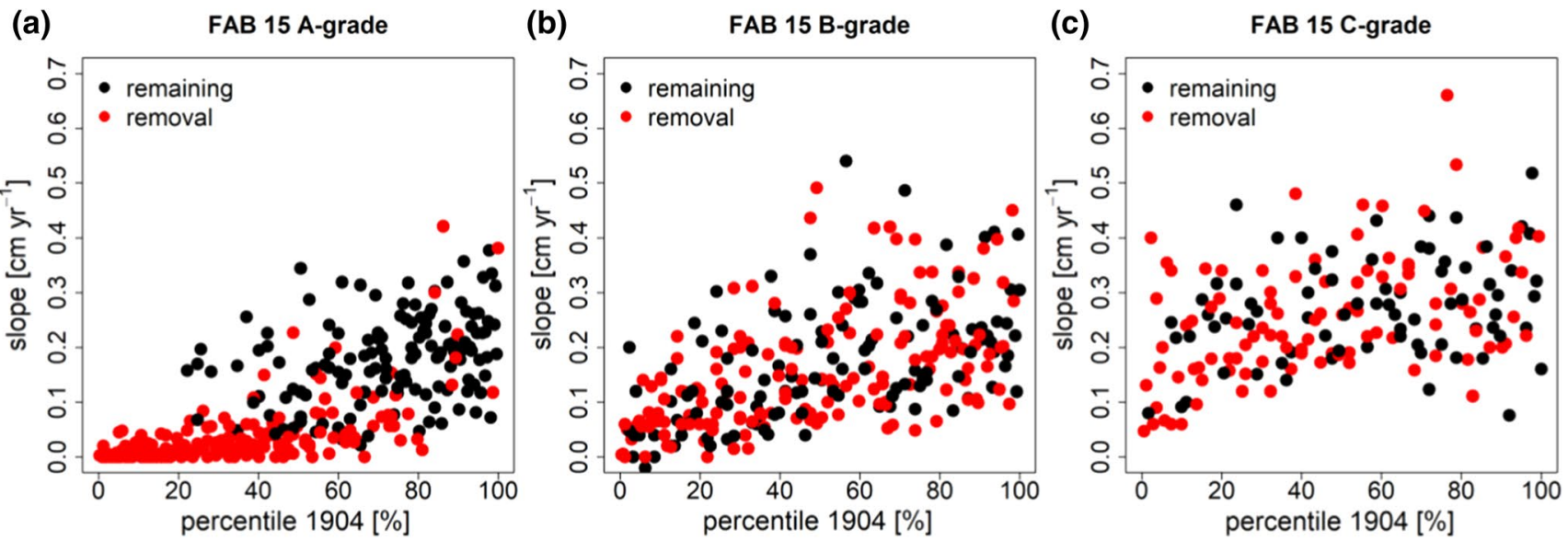

Fig. 4 Slopes of the course of stem diameter growth $\left(\mathrm{cm} \mathrm{yr}^{-1}\right)$ plotted over the percentile of stem diameter at the first individual tree survey in 1904. Black symbols represent remaining trees, red symbols tree that died or were removed between 1904 and 2010. Relationships are shown for the (a-c) A-, B-, and C-grade plots of the thinning trial in European beech Fabrikschleichach 15. 
(a)

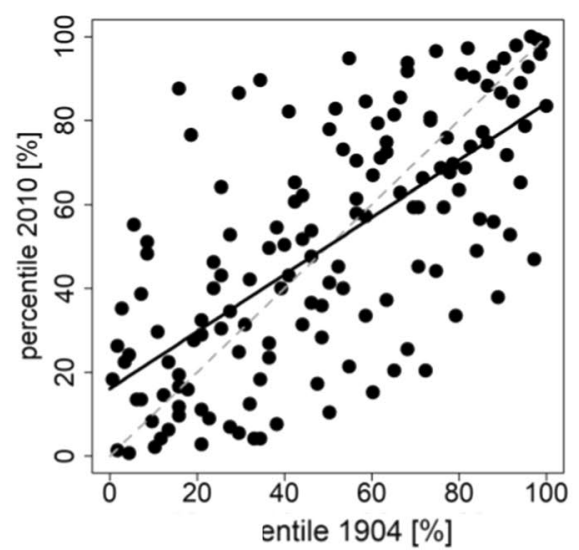

(b)

FAB 15 B-grade

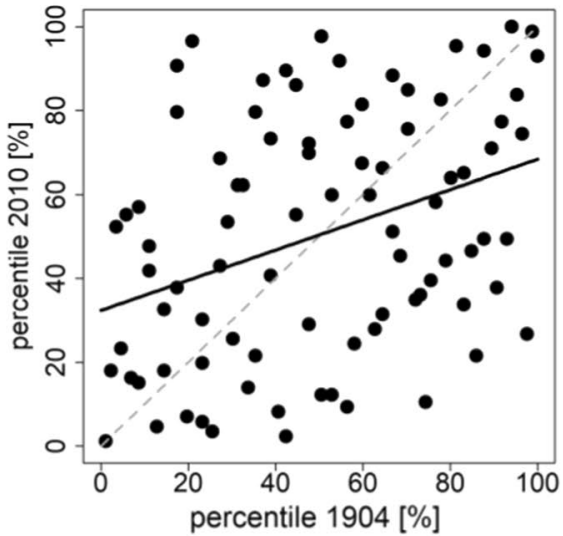

(c)

FAB 15 C-grade

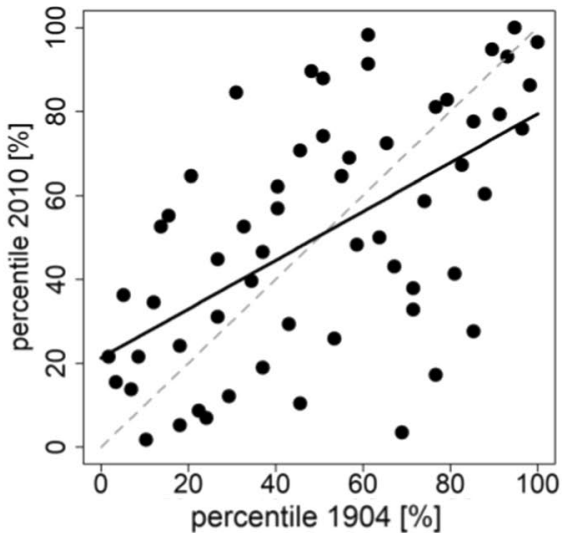

Fig. 5 Stem diameter percentiles of the survey in 2010 plotted over the respective percentiles of the survey in 1904 shown for the A-, B-, and C-grade plots of the thinning trial in European beech Fabrikschleichach 15 . The black straight line shows the observed non- stationariness of size ranking (for statistical characteristics of the underlying regression and correlation see Table 3). The bisectoral line would indicate stationarity of the ranking
Table 3 Statistical characteristics of the relationship perc $_{2010}=a_{0}+a_{1} \times$ perc $_{1904}$ fitted to the data of the three thinning plots separately and to the pooled data of all three plots

\begin{tabular}{lrllllllll}
\hline group & \multicolumn{1}{c}{$\mathrm{n}$} & $\mathrm{a}_{0}$ & $\mathrm{SE}\left(\mathrm{a}_{0}\right)$ & $\mathrm{p}$-value & $\mathrm{a}_{1}$ & $\mathrm{SE}\left(\mathrm{a}_{1}\right)$ & $\mathrm{p}$-value & $\mathrm{R}^{2}$ & $p$-value \\
\hline A-grade & 145 & 16.0765 & 3.5556 & $<0.001$ & 0.6807 & 0.0613 & $<0.001$ & 0.46 & $<0.001$ \\
B-grade & 86 & 32.3736 & 5.9288 & $<0.001$ & 0.3600 & 0.1018 & $<0.001$ & 0.13 & $<0.001$ \\
C-grade & 58 & 21.9593 & 6.3596 & $<0.001$ & 0.5813 & 0.1088 & $<0.001$ & 0.34 & $<0.001$ \\
all & 289 & 21.9594 & 2.8333 & $<0.001$ & 0.5653 & 0.0487 & $<0.001$ & 0.32 & $<0.001$ \\
\hline
\end{tabular}

Slopes $a_{1}=1$ would indicate a stationarity of the social ranking over the considered 106-year time period. Significant deviations from $a_{1}=1$ indicate non-stationarity, i.e., a significant social drift

\section{Differences between the courses of the stem growth of the $\mathbf{1 0 0}$ tallest trees at the beginning and end of the survey period $(\mathrm{H} 2)$}

It has been frequently shown that small and suppressed trees, which represent low percentiles in the diameter distribution, are frequently outcompeted under self-thinning conditions or removed by moderate or heavy thinning from below as shown in Fig. 1a-c. More interesting is how the dominant trees, e. g., the 100 tallest trees develop, as they dominate the stand structure and they also represent a significant portion of the standing volume and volume growth.

On the A-, B-, and C-grade plots, respectively, 40, 60, and $44 \%$ of the 100 tallest trees in 1904 were replaced by others till 2010; with other words, they were replaced by social climbers and down-ranked below the 100 tallest. Figure 6 shows the growth trajectories of the climbers and the social losers.

Figure 6a (red broken lines) visualizes for the A-grade (self-thinning) the stem diameter growth of those trees which belonged to the 100 tallest trees in 1904 but lost this status until 2010; most of them were comparatively tall at the beginning but have a shallow course of diameter growth.
The black lines, in contrast, represent the social climbers, i.e., those trees that did not belong to the 100 tallest in 1904 but in 2010. All of them were rather small at the beginning but steep in the diameter growth from 1904 to 2010.

The tendency of the losers and climbers is similar in the stands with moderate and heavy thinning from below (B- and C-grade) (Fig. 6b and c). The losers show even shallower courses of diameter growth and the social climbers have steeper stem diameter curves compared with the A-grade (Fig. 6a).

Figure 7 visualizes the mean course of stem diameter growth of the 100 tallest trees at the beginning (black) and at the end of the survey period (red). The differences of the diameter growth trajectories between both social groups (quickstarters versus latecomers) were tested by Model 2 for each thinning grade separately (Supplement Tables 1, 2 and 3 ) and by Model 3 for all three plots together (Table 4).

On all three plots Model 2 showed that the intercept of the diameter-age relationship of the survivors was significantly lower $(p<0.001)$ and the slope steeper $(p<0.001)$ than the diameter-age relationship of the beginners (Supplement Table 1,2 and 3). The slopes of the survivors were by 

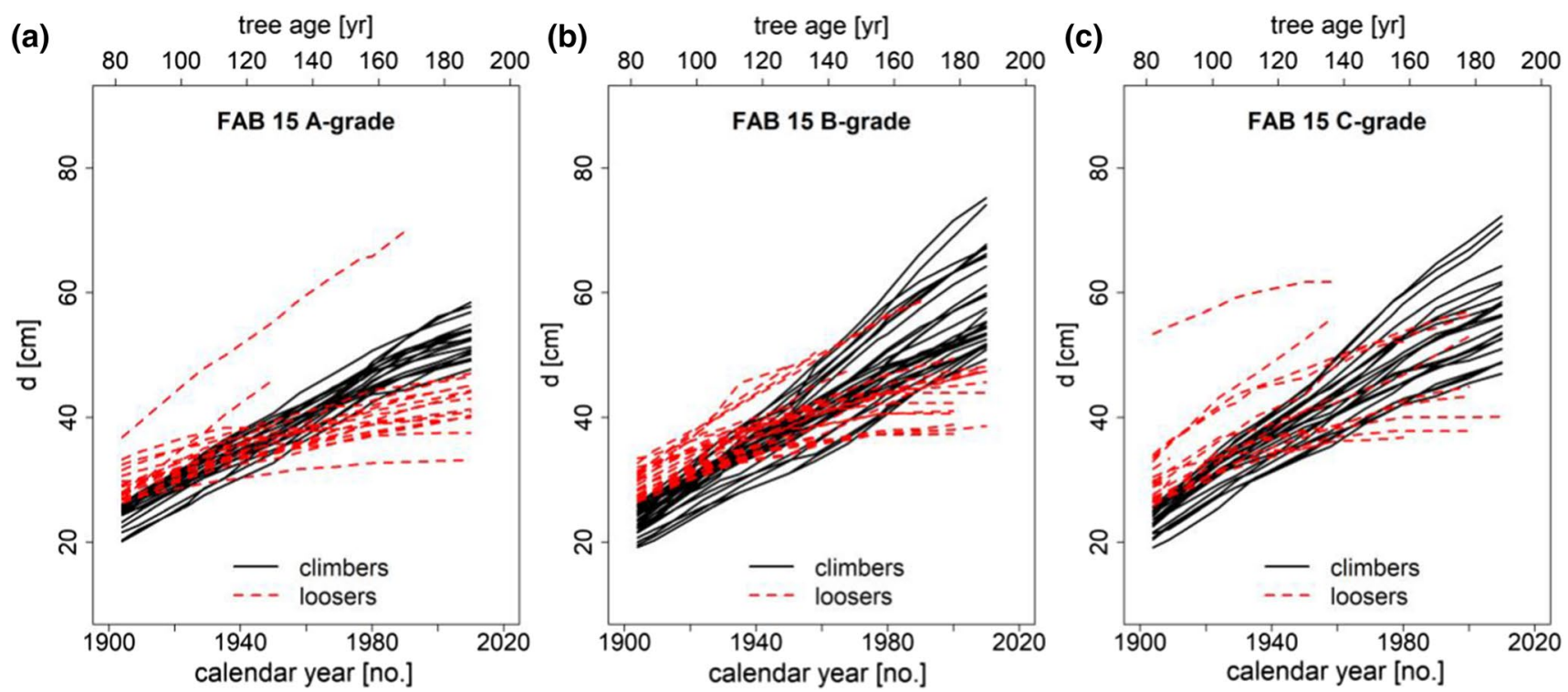

Fig.6 Stem growth of the social climbers (black) and social losers (red broken line) shown for the A-, B-, and C-grade plots (a-c) of the thinning trial in European beech Fabrikschleichach 15. The red lines represent trees which were among the 100 tallest trees in 1904 but not

among the tallest 100 trees in 2020 (social losers). Black lines represent trees which were not among the 100 tallest in 1904 but among the tallest 100 trees in 2020 (social climbers)

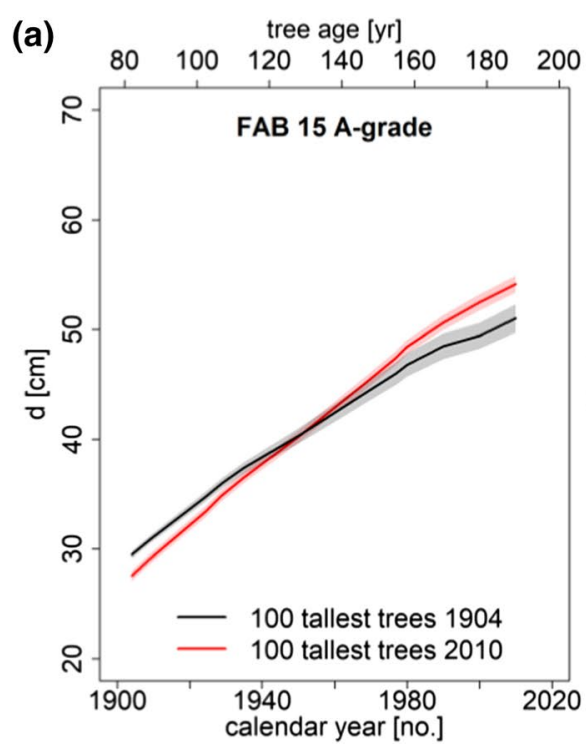

(c)

$\begin{array}{lllllll}\text { (b) } & 80 e \text { age }[y r] \\ 80 & 100 & 120 & 140 & 160 & 180 & 200\end{array}$

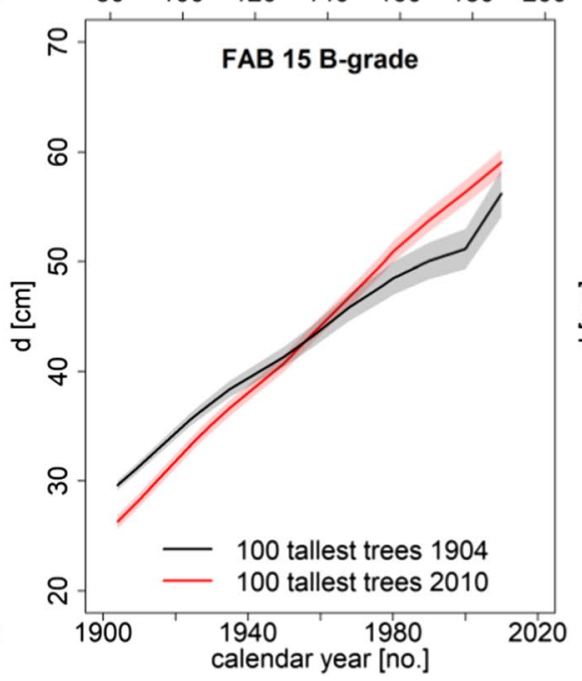

(c) tree age [yr]

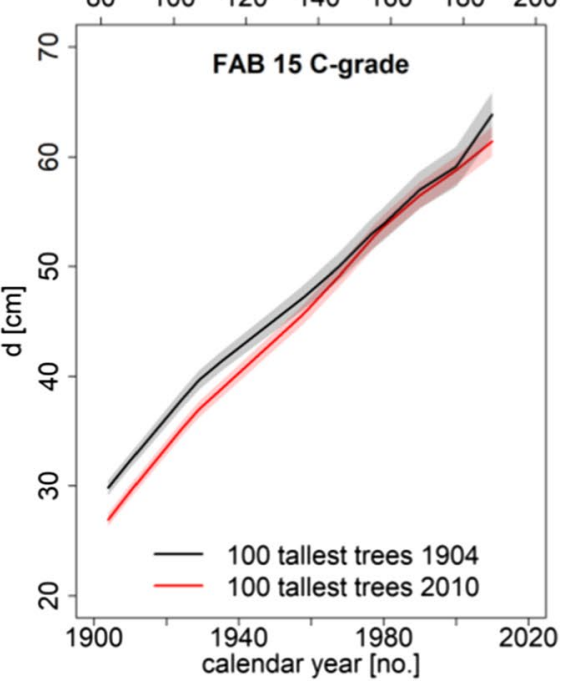

Fig. 7 Mean $( \pm$ SE) of the stem diameter shown for the 100 tallest trees in 1904 (black) compared with the tallest trees in 2010 (red). The deviation between the growth trend of the initially and finally

$23.75,37.34$ and $8.75 \%$ steeper on the A, B-, and C-grade, respectively.

Table 4 shows the analogous statistical characteristics of the pooled dataset analyzed by Model 3, i.e., the test of survivors versus beginners over all three thinning grades. Compared with the quickstarters (group $=0$ ) the latecomers (group $=1)$ had a lower intercept $\left(a_{2}=-7.5925\right)$ and a dominating trees is shown for the (a-c) A-, B-, and C-grade plots of the thinning trial in European beech Fabrikschleichach 15

higher slope ( $\left.a_{3}=0.0565\right)$. This overall analysis underpins the significantly lower intercept $(p<0.001)$, steeper slope $(p<0.001)$; the percental increase in the slope was on average $23.37 \%$. The reported increase in steepness in percent resulted from the division of the delta slope of the survivors $\left(a_{1}=0.0565\right)$ by the slope of the beginners $\left(a_{0}=0.2412\right)$. 
In summary, all analyses revealed a significant effect of the social group on both intercept and slope of the $\mathrm{d}-$ age relationship. Compared with the quickstarters (group $=0$ ) the latecomers (group $=1$ ) had a lower intercept and a steeper slope. With other words, the survivors have a steeper and longer lasting growth then the beginners.
The comparison between the characteristics of the social climbers and the originally dominant trees in Table 5 revealed that the climbers, although subdominant in the past, achieved similar stem and crown characteristics till the last survey in 2010. They had only minor and non-significant shorter crowns and lower crown ratios (Table 5, column 3
Table 4 Results of fitting the linear mixed effect model of tree diameter dependent on tree age of quickstarters (group 0 ) versus latecomers (group 1) to the combined A-, B-, and C-grade data (Model 3)
Table 5 Comparison of the tree dimensions between the 100 tallest starters in 1904 measured in 2010 and the climbers from 1904 to 2010 measured in 2010 (column 3 vs. 4)

\begin{tabular}{lllll}
\hline Fixed effect variable & Fixed effect parameter & Estimate & Std. Error & $p$ \\
\hline intercept & $a_{0}$ & 9.9520 & 0.4963 & $<0.001$ \\
age & $a_{1}$ & 0.2412 & 0.0024 & $<0.001$ \\
group & $a_{2}$ & -7.5925 & 0.4407 & $<0.001$ \\
age $\times$ group & $a_{3}$ & 0.0565 & 0.0031 & $<0.001$ \\
& Random Effect & Std. Dev & & \\
Plot level & $b_{i}$ & 1.8158 & \\
Tree level & $b_{i j}$ & 5.3920 & \\
& Residuals & Std.Dev & & \\
& $\epsilon_{i k}$ & 3.0223 & & \\
\hline
\end{tabular}

The underlying model was $d_{\mathrm{ijk}}=a_{0}+a_{1} \times \operatorname{age}_{\mathrm{ijk}}+a_{2} \times \operatorname{group}_{\mathrm{ij}}+a_{3} \times \operatorname{age}_{\mathrm{ijk}} \times \operatorname{group}_{\mathrm{ij}}++b_{\mathrm{i}}+b_{\mathrm{ij}}+\epsilon_{\mathrm{ijk}}$. AIC comparisons suggested using random effects at the plot and tree level. Number of observations $=3578$ from 216 trees on 3 plots.

\begin{tabular}{|c|c|c|c|c|c|c|c|c|c|}
\hline \multirow[t]{2}{*}{ Variable } & \multirow[t]{2}{*}{ Unit } & \multicolumn{2}{|c|}{$\begin{array}{l}100 \text { tallest starters } \\
\text { in } 1904 \text { measured } \\
\text { in } 2010\end{array}$} & \multicolumn{2}{|c|}{$\begin{array}{l}\text { Climbers from } \\
1904 \text { to } 2010\end{array}$} & \multicolumn{2}{|c|}{$\begin{array}{l}100 \text { tallest final } \\
\text { trees in } 2010 \\
\text { measured in } 2010\end{array}$} & \multicolumn{2}{|c|}{$\begin{array}{l}\text { Losers from } \\
1904 \text { to } 2010\end{array}$} \\
\hline & & Mean & $\pm \mathrm{SE}$ & Mean & $\pm \mathrm{SE}$ & Mean & $\pm \mathrm{SE}$ & Mean & $\pm \mathrm{SE}$ \\
\hline d & $\mathrm{cm}$ & 56.1 & 1.110 & 56.4 & 0.796 & 58.2 & 0.696 & 43.4 & 0.856 \\
\hline $\mathrm{h}$ & $\mathrm{m}$ & 39.3 & 0.409 & 40.2 & 0.384 & 40.1 & 0.266 & 35.7 & 1.049 \\
\hline slenderness & $\mathrm{m} \times \mathrm{m}^{-1}$ & 0.67 & 0.015 & 0.68 & 0.014 & 0.66 & 0.011 & 0.78 & 0.024 \\
\hline $\mathrm{cl}$ & $\mathrm{m}$ & 20.1 & 0.715 & 19.1 & 0.778 & 19.8 & 0.522 & 17.2 & 2.827 \\
\hline cratio & $\mathrm{m} \times \mathrm{m}^{-1}$ & 0.51 & 0.017 & 0.47 & 0.018 & 0.50 & 0.012 & 0.48 & 0.077 \\
\hline $\mathrm{cd}$ & $\mathrm{m}$ & 7.5 & 0.125 & 7.6 & 0.117 & 7.8 & 0.096 & 6.3 & 0.118 \\
\hline сра & $\mathrm{m}^{2}$ & 47.0 & 1.613 & 46.9 & 1.545 & 50.8 & 1.309 & 32.8 & 1.546 \\
\hline
\end{tabular}

Comparison between the 100 tallest final trees in 2010 measured in 2010 and the losers from 1904 to 2010 measured in 2010 (column 5 vs. 6). Shown are the means and standard errors; significant differences $(p<0.05)$ are printed in bold letters

$\mathrm{d}$, diameter at breast height; h, tree height; slenderness, ratio h/d; cl, crown length; cratio, crown length/tree height; cd, crown diameter; cpa, crown projection area

\begin{tabular}{llllllllllll}
\hline $\begin{array}{l}\text { Thinning } \\
\text { grade }\end{array}$ & $\begin{array}{l}\text { Stand } \\
\text { age }\end{array}$ & & $\mathrm{d}$ & $\mathrm{h}$ & $\mathrm{BA}$ & $\mathrm{V}$ & $\begin{array}{l}\text { Current } \\
\text { annual vol- } \\
\text { ume growth } \\
\mathrm{m}^{3} \mathrm{ha}^{-1} \mathrm{yr}^{-1}\end{array}$ & $\begin{array}{l}\text { Mean annual } \\
\text { volume } \\
\text { growth } \\
\mathrm{m}^{3} \mathrm{ha}^{-1} \mathrm{yr}^{-1}\end{array}$ & $\begin{array}{l}\text { Total } \\
\text { volume } \\
\text { yield } \\
\mathrm{m}^{3} \mathrm{ha}^{-1}\end{array} \mathrm{~m}^{3} \mathrm{ha}^{-1}$ & $\begin{array}{l}\text { Removed } \\
\text { volume }\end{array}$ \\
\hline $\mathrm{A}$ & 188 & 381 & 44.1 & 36.1 & 58.4 & 1120 & 8.3 & 7.8 & 1460 & $\begin{array}{l}\text { Inter- } \\
\text { mediate } \\
\text { yield }\end{array}$ \\
$\mathrm{B}$ & 188 & 194 & 54.0 & 39.8 & 43.5 & 920 & 13.4 & 9.1 & 1715 & 607 & 35.4 \\
$\mathrm{C}$ & 188 & 128 & 62.4 & 41.5 & 39.3 & 865 & 12.9 & 8.8 & 1655 & 633 & 38.2 \\
\hline
\end{tabular}

The underlying Model 4 was slope ${ }_{1990-2010}=a_{0}+a_{1} \times$ perc $_{1904}+a_{2} \times$ perc $_{2010}+\epsilon_{\mathrm{k}}$. Slope, annual diameter increase from 1990 to $2010\left(\mathrm{~cm} \mathrm{yr}^{-1}\right)$ and perc ${ }_{1904}$ and perc 2010 diameter percentiles in 1904 and 2010 $(\%)$. 
vs. 4). The social losers, although dominant in 1904, were significantly lower in tree diameter, height, crown diameter and crown projection area compared with the 100 tallest final trees in 2010 (Table 5, column 5 vs. 6). The stem slenderness of the losers was significantly higher (slenderness of 0.78 versus 0.66 ) due to their decreased social position within the stands.

\section{Effect of the social drift on the slope of the current diameter development (H3)}

The effects of the past and present social position within the stand on the current slope of the diameter development according to Model 4 are presented in Table 6. The 30-year slope $_{1990-2010}$ of the diameter development was chosen, as growth trend analyses often cover a 20 -year period. Table 6

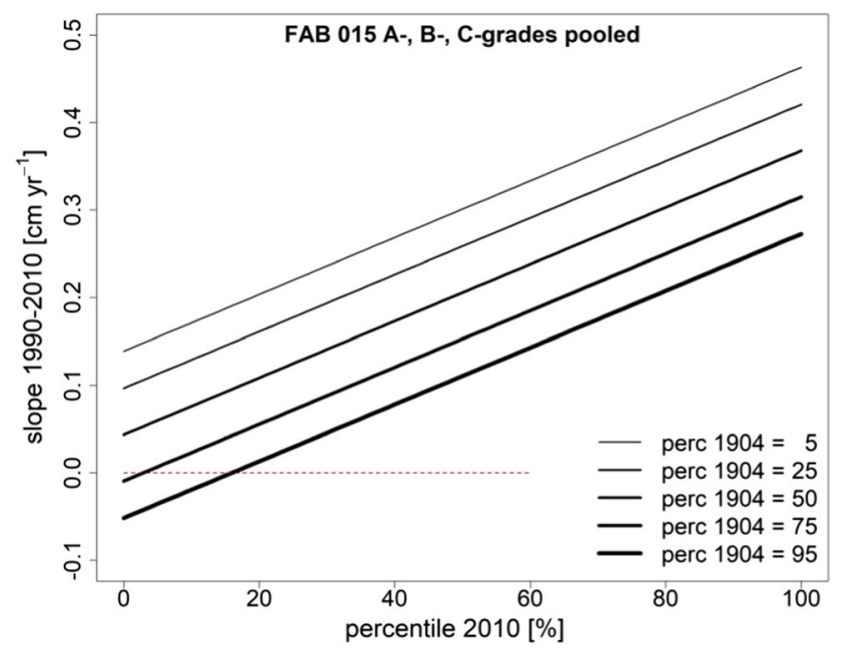

Fig. 8 Dependency of the slope of the diameter growth in 1990-2010 on the current social position represented by the diameter percentile 2010 and on the past social position represented by the diameter percentile 1904. For underlying Model 4 see Sect. 2.2 and for model parameters see Table 6 shows that the growth trend in terms of the slope of the diameter development from 1990 to 2010 (mean stem diameter increase in $\mathrm{cm} \mathrm{yr}^{-1}$ ) was positively influenced by the current diameter percentile ( $\left.\operatorname{perc}_{2010}\right)$. The higher the current social position of the trees ( perc $\left._{2010}\right)$, the steeper their diameter slopes $\left(a_{2}=0.0026-0.0037\right)$. However, the social tree position in the past ( perc $_{1904}$ ) decreased the diameter growth trend at present $\left(a_{1}=-0.0022\right.$ to -0.0012$)$. This means that trees that were dominant in the past had a shallower growth trend at present, whereas subdominant trees in the past had steeper diameter growth slopes at present. In all cases the effects were highly significant $(p<0.001)$ and the $R^{2}$-values ranged from 0.58 to 0.79 .

Social dominance in 2010 certainly increased the slope of the diameter growth in the period 1990-2010, i. e. taller trees grow better than smaller, subdominant ones. The positive regression coefficients $a_{2}$ in Table 6 show that this applies for the trees of all three thinning grades and also for the pooled data of the A-, B-, and C-grade plots together. Figure 6 visualizes this finding for the pooled data (for statistical characteristics see last row in Table 6). However, ceteris paribus, those trees that were subdominant in the past (when first measured individually in 1904) have significantly steeper slopes at present than the former dominant ones. The steepness of the slope of the diameter growth in 1990-2010 increases with decreasing social position in 1904. This means that the present slope is the higher for trees with low ranking in the past and decreases with increasing perc ${ }_{1904}$ as follows $5>25>50>75>95$ (see Fig. 8). Obviously, slow growth in early age is associated with longer continuing growth in advanced tree age.

Table 7 summarizes the relative effect of the past social position (percentile in 1904) and the present social position (percentile in 2010) of trees on their current growth trend (slope in 1990-2010). It reflects for instance that currently dominant trees $\left(\right.$ perc $\left._{2010}=100 \%\right)$ that were co-dominant in the past ( $\operatorname{perc}_{1904}=90 \%$ ) have a by $8 \%$ steeper slope at present. If the same trees were only subdominant or even
Table 7 Relative effect of the past social position in the stand on the diameter growth slope in 1990-2010

\begin{tabular}{rrrrrrr}
\hline $\operatorname{perc}_{2010}(\%)$ & 100 & 90 & 80 & 70 & 60 & 50 \\
\hline $\operatorname{perc}_{1904}(\%)$ & & & & & & \\
100 & 0 & 0 & 0 & 0 & 0 & 0 \\
90 & 8 & 9 & 11 & 13 & 16 & 21 \\
80 & 16 & 18 & 21 & 26 & 32 & 42 \\
70 & 24 & 28 & 32 & 39 & 48 & 64 \\
60 & 32 & 37 & 43 & 51 & 64 & 85 \\
50 & 40 & 46 & 54 & 64 & 80 & 106 \\
\hline
\end{tabular}

Based on the model slope ${ }_{1990-2010}=0.1495-0.0021 \times$ perc $_{1904}+0.0032 \times$ perc $_{2010}$ the growth trend of the dominant trees in 1904 was set on $100 \%$. The table displays to what extend any co- and subdominance in 1904 (in terms of percentiles in 1904 below 100\%, from top to bottom) increases the present growth trend compared with predominant trees. The effect is shown for dominant and also subdominant trees in 2010 (in terms of percentiles in 2010, from left to right) 
suppressed in 1904 (perc $_{1904}=80 \%$ or $50 \%$ ), the slope is by $40 \%$ steeper than the one of trees that were predominant in 1904 (second column in Table 7). The analogous, but even stronger positive effect of the past social position on the present growth trend is also shown for currently codominant, subdominant, and suppressed trees ( $\operatorname{perc}_{2010}=90-50 \%$, from the third to seventh column).

\section{Discussion}

\section{Growth trend bias by retrospective sampling of the survivors in mature forest stands}

This study was mainly motivated by a series of recently published papers which detected growth events and trends methodologically based on increment coring of survivors in mature forest stands (Bosela et al. 2016; del Río et al. 2014 , 2017). The revealed growth trends were mainly ascribed to the extension of the growing season, warming, increase in nitrogen deposition and the atmospheric $\mathrm{CO}_{2}$-concentration (Dulamsuren et al. 2017; Pretzsch et al. 2020a-c). For instance, Pretzsch et al. (2020a and b) reported for European beech in Central Europe a diameter growth increase of $30-40 \%$ in the last 100 years. The lastmentioned studies were based on retrospective tree ring analyses by increment boring of dominant survivor trees in mature and older beech stands and raised the question to what extend the reported growth trends may be a sampling bias. The study in hand found that the growth trend of the survivors in a 188 years old stand was on average by $23 \%$ steeper than the growth of the original in 1904 dominant trees. Compared with the on average $23 \%$ overestimation resulting from the survivor bias, the observed increase of $30-40 \%$ is still considerably higher. However, about a half of the diagnosed growth acceleration ascribed to environmental changes may be simply caused by social drift and results in a survivor bias when stand growth is analyzed.

The results are relevant for understanding and improving the sampling design. In stands with target-diameter cutting, which has become a very common method of prolongated final harvest, the tall trees with already shallower diameter growth trajectories are continuously removed. Sampling of the remaining trees in such stands would likely estimate a growth curve and trend that may be representative for the survivors.

Table 7 corroborates that the probability of an over-estimation of the current growth trend in the analyzed European beech stand increases when mainly trees are sampled that are currently subdominant. And the over-estimation is the higher the more subdominant the sample trees were in the past. So, the less dominant trees were in the past, the higher is their growth trend at present, and the less representative is their trend for the long-term dominant trees of a stand.

The main cause of the diverging growth trend of survivors from originally dominant trees is that tree growth depends rather on tree size or mass than on tree age (Pretzsch 2020c; Stephenson et al. 2014). The faster trees grow at the beginning the earlier they may slow down later; this has been shown repeatedly for forest (Guttenberg 1915; Pretzsch 2020a-c; Zeide 1993) and urban trees (Smith et al. 2019). Recent studies stress that the growth of many tree species is accelerated and continues longer than expected and reported in textbooks (Pretzsch 2020c ; Sillett et al. 2015a and b; Stephenson et al. 2014). Probably the revealed social drift is reinforced by this growth acceleration, i.e., the survivor bias may even increase with increasing growth trend as the size growth of the dominant trees is accelerated, their slowing down and removal preponed and the social climbing of their latecoming neighbors, preferentially sampled in older stands, may be promoted.

\section{Implication for tree and stand dynamics}

The study in hand shows that the effects of social positions and other legacy effects in the past on the present growth are relevant and that their revelation requires long-term survey on experimental spatially explicitly inventored permanent plots. For analyzing and modelling individual tree growth this information is hardly substitutable by temporary plots or retrospective analyses based on tree ring analyses. Best insight into the effects of the trees' history on their behavior at present and for respective model parameterization provides long-term experiments with repeated measurements of all trees, their positions, survival status and sizes (Nagel et al. 2012; Pretzsch et al. 2019).

Our study corroborates that individual tree growth may be followed and described along tree age, but that it is primarily depending on current tree size. Suppressed trees with lagged size development can continue long in growth, quickstarters may slowdown earlier. This confirms the concept of allometrically based growth models that use trees size instead of age as main predictor (Niklas 1994; Pretzsch et al. 2002). The results also suggest that tree history in terms of past social position, social drift, inner tree structure and tree morphology can significantly co-determine current tree growth. That tree history may be relevant for understanding growth was recently shown by Camarero et al. (2018) and Nothdurft and Engel (2020) who introduced lag models for consideration of such effects.

Models that consider the individual trees' growth courses and their determination by present and past characteristics may better predict the asynchronous rhythm of growth trajectories as show for the individual tree level in Fig. 6. The social drift and asynchrony in growth caused by a 
combination of quickstarters and latecomers may result in a prolonged and stabilized growth as shown for the stand level in Fig. 1. Such a stabilization and persistence of stand growth caused by the interplay of quickstarters and latecomers is hardly predictable by stand level models based on mean tree or sum values (Hanewinkel et al. 2000; Lindner et al. 1997; Pretzsch et al. 2008).

\section{Silvicultural consequences of the social drift}

Of considerable relevance for the silviculture of European beech stands were the long persisting courses of individual growth, the high social drift of the trees during the 106-year survey period, and the finding that thinning can considerably break the social order and ranking and can promote the social climbing. Interesting were furthermore the significantly positive effects of the early social status on the growth trend in the advanced age and that the social climbers finally reached similar tree dimensions as the quickstarters. Beech is the dominant tree species in large parts of temperate Europe and a typical example of a late-successional canopy tree, including remarkable shade tolerance at early life stages (Nagel et al. 2014; Leuschner and Ellenberg 2017). European beech has an especially high ability to survive in the shade and high morphological plasticity (Dieler et al. 2013; Barbeito et al. 2017; Bayer et al. 2013). The potential of social drift that we revealed in this study is supported by the shade tolerance and morphological plasticity of European beech.

It is well documented that European beech can reach longevities of 300-500 years (Ellenberg and Leuschner 2010, p. 104, Di Filippo et al. 2007); however, tree and stand growth are commonly assumed to decrease at advanced ages (Assmann 1961, p. 80, Mitscherlich 1970, p. 83). Although the analyzed trees in our study were in advanced ages, their growth did not yet show any slowdown in stem diameter growth. This was in line with the results of Pretzsch et al. (2020a and c), who found a linear diameter growth trend for Norway spruce, silver fir and beech trees in mixed mountain forests. This long continuation of individual tree growth in combination with the ability of social upclimbing may considerably increase the silvicultural flexibility. Quickstarters reduce their growth earlier than latecomers. Thus at advanced age any stand growth reductions by quickstarters may be compensated by latecomers that take their social rank or even overtake them in size. Thus, the combination of quickstarters and latecomers, caused by the social drift, may result in a stable and long continuation of stand growth. The ability to alter the social position even in rather late stand development phases results in a reserve of target trees and flexibility in the timing of harvest. The asynchrony of growth rhythm means that the individual trees arrive at their target size for economically optimal harvest asynchronously. In contrast to plantations where all trees are kept dominant and simultaneously in their social rank and course of growth by wide spacing and permanent density reduction, the analyzed naturally regenerated European beech stands represent more asynchronous individual tree growth patterns. The more variable and asynchronous the growth rhythm, the higher the flexibility in thinning from above (Vuokila 1977) or target diameter cutting (Sterba and Zingg 2001; Zell et al. 2004). Non-stationarity of the trees' social status may on the other hand cause structural heterogeneity, that is disadvantageous for wood quality (Rais et al. 2020). Reduction of social rank can mean crown recession and mortality of branches causing wood quality reduction (Pretzsch and Rais 2016). On the other hand, structural heterogeneity is often associated with richness of habitats and species diversity (Dieler et al. 2017).

\section{Conclusion}

The social drift of trees during stand development resulted partly from the dependency of the tree growth from tree size. Quickstarters decreased earlier and latecomers started slower but proceeded longer. This may cause a drift of social ranking over time in terms of changing size dominance. It can stabilize stand growth and increase the silvicultural flexibility of stand management regarding final harvest, threshold diameter cutting, natural regeneration, and transformation.

However, the non-stationarity of social status and asynchrony of growth rhythm may cause a considerable sampling bias if the growth trend of dominant trees or of the stand as a whole is deduced from the latecomers and survivors. As their course of growth is still steeper than the main collective of the trees in a stand, sampling of the latecomers and survivors may cause an overestimation of the current growth trend. In this study the sampling bias of growth trend in terms of the slope of the 100 dominant survivors in relation to the slope of the 100 originally dominant trees was $+23 \%$ on average. Analyses of growth trends based on long-term experiments may avoid such bias. However, long-term experiments with full tree inventory are rare and science often has to rely on retrospective analyses via increment boring.

In such cases the revealed bias should be kept in mind for cautious interpretation or adjustment of the quantified trends. Sampling that aims at the analyses of growth trends of the dominant trees that are relatively unbiased by competitive effects should therefore select those dominant trees that always belonged to the dominant collective. They are easy to choose in case of permanent plots, in case of sampling by increment coring it may help to select those trees for further analyses that belong to the dominant collective 
at present and whose reconstructed diameters indicate also a membership to the dominating collective in the past. Trees with ring width pattern that indicate a slow start or even a suppression phase are likely to be latecomers and social climbers that flaw any growth trend analyses. They should be excluded if the study aims at revelation of reliable trends of the long-term dominant trees.

Ongoing studies based on long-term experiments of other species, thinning methods, and site conditions may further quantify the potential survivor sampling bias and other consequences of the social drift of individual trees during stand development.

\begin{abstract}
Acknowledgements The author would like to acknowledge networking support by the COST (European Cooperation in Science and Technology) Action CLIMO (Climate-Smart Forestry in Mountain RegionsCA15226) financially supported by the EU Framework Programme for Research and Innovation HORIZON 2020. The publication is also part of the CARE4C project that has received funding from the European Union's HORIZON 2020 research and innovation programme under the Marie Skłodowska-Curie grant agreement No 778322. Thanks go also to the Bayerische Staatsforsten (BaySF) for supporting the establishment and maintenance of the underlying long-term experiments and to the Bavarian State Ministry for Nutrition, Agriculture, and Forestry for permanent support of the project W07, entitled "Long-term experimental plots for forest growth and yield research" (\# 7831-22209-2013). The author wishes to thank Peter Biber for revising the statistical parts of this manuscript and Charlotte Marie Pretzsch for the language revision. Thanks also go to anonymous reviewers for their constructive criticism.
\end{abstract}

Author contributions HP initiated and conceptualized the study, evaluated the data, wrote and revised the manuscript.

Funding Open Access funding enabled and organized by Projekt DEAL.

\section{Compliance with ethical standards}

Conflict of interest The author declares that he has no conflict of interest.

Open Access This article is licensed under a Creative Commons Attribution 4.0 International License, which permits use, sharing, adaptation, distribution and reproduction in any medium or format, as long as you give appropriate credit to the original author(s) and the source, provide a link to the Creative Commons licence, and indicate if changes were made. The images or other third party material in this article are included in the article's Creative Commons licence, unless indicated otherwise in a credit line to the material. If material is not included in the article's Creative Commons licence and your intended use is not permitted by statutory regulation or exceeds the permitted use, you will need to obtain permission directly from the copyright holder. To view a copy of this licence, visit http://creativecommons.org/licenses/by/4.0/.

\section{References}

Ammer C, Albrecht H, Borchert H, Brosinger F, Dittmar C, Elling W, Ewald J, Felbermeier B, Gilsa VH, Kenk G (2005) Zur zukunft der buche (Fagus sylvatica L.) in mitteleuropa. Kritische anmerkungen zu einem beitrag von rennenberg et al. Allg Forst-u J-Ztg 176(4):9-60

Assmann E (1970) The principles of forest yield study. Pergamon Press, Oxford, New York, p 506

Assmann E (1961) Waldertragskunde Organische Produktion, Struktur, Zuwachs und Ertrag von Waldbeständen. BLV Verlagsgesellschaft, München, Bonn, Wien, p 490

Assmann E (1950) Grundflächen- und volumenzuwachs der rotbuche bei verschiedenen durchforstungsgraden. Forstwiss Cent 69:256-286

Barbeito I et al (2017) Terrestrial laser scanning reveals differences in crown structure of fagus sylvatica in mixed vs. pure European forests. For Ecol Manag 405:381-390

Bayer D, Seifert S, Pretzsch H (2013) Structural crown properties of Norway spruce (Picea abies [L.] Karst) and European beech (Fagus sylvatica [L.]) in mixed versus pure stands revealed by terrestrial laser scanning. Trees 27(4):1035-1047

von Bertalanffy L (1951) Theoretische biologie: II. Band, stoffwechsel, wachstum, 2nd edn. A Francke AG, Bern, p 418

Biber P (2013) Kontinuität durch flexibilität-standardisierte datenauswertung im rahmen eines waldwachstumskundlichen informationssystems. Allg Forst-und Jagdztg 184(7/8):167-177

Blume H-P, Schad P (2015) 90 Years of soil classification of the IUSS. IUSS Bull 126:38-45

Borgaonkar HP, Sikder AB, Ram S (2011) High altitude forest sensitivity to the recent warming: a tree-ring analysis of conifers from Western Himalaya. India Quat Int 236(1-2):158-166

Bosela M, Štefančík I, Petráš R, Vacek S (2016) The effects of climate warming on the growth of European beech forests depend critically on thinning strategy and site productivity. Agric For Meteorol 222:21-31. https://doi.org/10.1016/j.agrformet.2016.03.005

Brienen RJ, Gloor M, Ziv G (2017) Tree demography dominates longterm growth trends inferred from tree rings. Glob Change Biol 23(2):474-484

Bruce D, Schumacher FX (1950) Forest mensuration, 3rd edn. The American Forestry Series, McGraw-Hill Inc, New York, Toronto, London, p 483

Burschel P, Huss J (1987) Grundriß des waldbaus. Pareys studientexte 49. Hambg Berl 352

Camarero J, Gazol A, Sangüesa-Barreda G, Cantero A, SánchezSalguero R, Sánchez-Miranda A, Ibáñez R (2018) Forest growth responses to drought at short-and long-term scales in Spain: squeezing the stress memory from tree rings. Front Ecol Evol 6:9

Cherubini P, Dobbertin M, Innes JL (1998) Potential sampling bias in long-term forest growth trends reconstructed from tree rings: a case study from the Italian Alps. For Ecol Manag 109(1-3): 103-118

del Río M, Schütze G, Pretzsch H (2014) Temporal variation of competition and facilitation in mixed species forests in $\mathrm{C}$ entral $\mathrm{E}$ urope. Plant Biol 16(1):166-176

del Río M, Pretzsch H, Alberdi I, Bielak K, Bravo F, Brunner A, Pach $M$ (2016) Characterization of the structure, dynamics, and productivity of mixed-species stands: review and perspectives. Eur J For Res 135(1):23-49

del Río M, Pretzsch H, Ruíz-Peinado R, Ampoorter E, Annighöfer P, Barbeito I, Fabrika M (2017) Species interactions increase the temporal stability of community productivity in Pinus sylvestrisFagus sylvatica mixtures across Europe. J Ecol 105(4):1032-1043

del Río M, Vergarechea M, Hilmers T, Alday JG, Avdagić A, Binder F, Bosela M, Dobor L, Forrester DI, Halilović V, Ibrahimspahić I, Klopcic M, Lévesque M, Nagel Th A., Sitkova Z, Schütze G, Stajić B, Stojanović D, Uhl E, Zlatanov T, Tognetti R, Pretzsch H (2020) Effects of elevation-dependent climate warming on intraand inter-specific growth synchrony in mixed mountain forests. For Ecol Manage 479:118587. https://doi.org/10.1016/j.forec 0.2020 .118587 
Dieler J, Pretzsch H (2013) Morphological plasticity of European beech (Fagus sylvatica L.) in pure and mixed-species stands. For Ecol Manag 295:97-108

Dieler J, Uhl E, Biber P, Müller J, Rötzer T, Pretzsch H (2017) Effect of forest stand management on species composition, structural diversity, and productivity in the temperate zone of Europe. Eur J Forest Res 136(4):739-766

Di Filippo A, Biondi F, Čufar K, De Luis M, Grabner M, Maugeri M, Presutti Saba E, Schirone B, Piovesan G (2007) Bioclimatology of beech (Fagus sylvatica L.) in the eastern alps: spatial and altitudinal climatic signals identified through a tree-ring network. J Biogeogr 34:1873-1892

Dobbertin M (2005) Tree growth as indicator of tree vitality and of tree reaction to environmental stress: a review. Eur J For Res 124(4):319-333

Duchesne L, Houle D, Ouimet R, Caldwell L, Gloor M, Brienen R (2019) Large apparent growth increases in boreal forests inferred from tree-rings are an artefact of sampling biases. Sci Rep 9(1):1-9

Dulamsuren C, Hauck M, Kopp G, Ruff M, Leuschner C (2017) European beech responds to climate change with growth decline at lower, and growth increase at higher elevations in the center of its distribution range (SW Germany). Trees 31(2):673-686

Ellenberg H, Leuschner C (2010) Vegetation Mitteleuropas mit den Alpen: in ökologischer, dynamischer und historischer Sicht, vol 8104. Utb, Ulmer, Stuttgart

Franz F, Bachler J, Deckelmann B, Kennel E, Kennel R, Schmidt A, Wotschikowsky U (1973) Bayerische waldinventur 1970/71, inventurabschnitt I: großrauminventur aufnahme- und auswertungsverfahren. Forstl Forschungsber München 11. 143

Franz F, Röhle H, Meyer F (1993) Wachstumsgang und ertragsleistng der buche. AFZ 6:262-267

Geßler A, Keitel C, Kreuzwieser J, Matyssek R, Seiler W, Rennenberg H (2007) Potential risks for European beech (Fagus sylvatica L) in a changing climate. Trees 21(1):1-11. https://doi.org/10.1007/ s00468-006-0107-x

Girardin MP, Bouriaud O, Hogg EH, Kurz W, Zimmermann NE, Metsaranta JM, Guo XJ (2016) No growth stimulation of Canada's boreal forest under half-century of combined warming and $\mathrm{CO} 2$ fertilization. Proc National Acad Sci 113(52):E8406-E8414

Guttenberg A. Von (1915). Wachstum und ertrag der fichte im hochgebirge. Franz Deuticke, Wien und Leipzig, 153 + appendix tables

Hanewinkel M, Pretzsch H (2000) Modelling the conversion from even-aged to uneven-aged stands of Norway spruce (Picea abies L. Karst.) with a distance-dependent growth simulator. For Eco Manag 134(1-3):55-70

Hilmers T, Avdagić A, Bartkowicz L, Bielak K, Binder F, Bončina A, Jaworski A (2019) The productivity of mixed mountain forests comprised of Fagus sylvatica, Picea abies, and Abies alba across Europe. For Int J For Res 92(5):512-522

Johann K (1993) DESER-Norm 1993. Normen der sektion ertragskunde im deutschen verband forstlicher forschungsanstalten zur aufbereitung von waldwachstumskundlichen dauerversuchen. Proc Dt Verb Forstl Forsch Sek Ertragskd UnterreichenbachKapfenhardt 96-104

Kennel R (1972) Buchendurchforstungsversuche in bayern von 1870 bis 1970. Forstl Forschu München 7:264

Kramer H (1988) Waldwachstumslehre. Paul Parey, Hamburg, Berlin, p 374

Leuschner C, Ellenberg H (2017) Ecology of Central European forests: vegetation ecology of Central Europe. Springer, Heidelberg

Lindner M, Sievänen R, Pretzsch H (1997) Improving the simulation of stand structure in a forest gap model. For Ecol Manag 95(2):183-195
Magin R (1959) Struktur und Leistung mehrschichtiger Mischwälder in den bayerischen Alpen. Mitt Staatsforstverwalt Bayerns 30:161

Markert BA, Breure AM, Zechmeister HG (2003) Definitions, strategies and principles for bioindication/biomonitoring of the environment. Trace Met Other Contam Environ 6:3-39

Martín-Benito D, Cherubini P, Del Río M, Cañellas I (2008) Growth response to climate and drought in Pinus nigra Arn. trees of different crown classes. Trees 22(3):363-373

Mitscherlich G (1970) Wald, wachstum und umwelt. 1. Band, form und wachstum von baum und bestand. JD Sauerländer's Verlag, Frankfurt am Main 143

Nagel J, Spellmann H, Pretzsch H (2012) Zum Informationspotenzial langfristiger forstlicher versuchsflächen und periodischer waldinventuren für die waldwachstums-kundliche forschung. Allg Forstund Jagdztg 183(5/6):111-116

Nagel TA, Svoboda M, Kobal M (2014) Disturbance, life history traits, and dynamics in an old-growth forest landscape of southeastern Europe. Ecol Appl 24(4):663-679

Nehrbass-Ahles C, Babst F, Klesse S, Nötzli M, Bouriaud O, Neukom R, Frank D (2014) The influence of sampling design on treering-based quantification of forest growth. Glob Change Biol 20(9):2867-2885

Niklas KJ (1994) Plant allometry. Univ Chicago Press, Chicago, IL

Nothdurft A, Engel M (2020) Climate sensitivity and resistance under pure-and mixed-stand scenarios in lower Austria evaluated with distributed lag models and penalized regression splines for treering time series. Eur J For Res 139(2):189-211

Pinheiro J et al. R Core Team. (2018) Nlme: linear and nonlinear mixed effects models. R package version 3.1-137. R Found Stat Comput. Retrieved from https://cran.r-project.org/web/packages/nlme (accessed 19 Jul. 2018)

Pretzsch H (1999) Waldwachstum im Wandel. Forstwiss Cent Ver Mit Tharandter Forstl Jahrb 118(1-6):228-250

Pretzsch H (2002) Grundlagen der Waldwachstumsforschung. Blackwell Wissenschafts-Verlag, Berlin, Wien, p 414

Pretzsch H (2009) Forest dynamics, growth and yield. Springer, Berlin, p 664

Pretzsch H (2019) Grundlagen der Waldwachstumsforschung, 2nd edn. Springer, Berlin, Germany, p 664

Pretzsch H (2020) The course of tree growth theory and reality, arthur tamm review. For Ecol Manag 478:118508. https://doi. org/10.1016/j.foreco.2020.118508

Pretzsch H, Biber P, Durský J (2002) The single tree-based stand simulator SILVA: construction, application and evaluation. For Ecol Manag 162(1):3-21

Pretzsch H, Hilmers T, Biber P, Avdagic A, Binder F, Bončina A, Bosela M, Dobor L, Forrester DI, Lévesque M, Ibrahimspahić A, Nagel TA, del Rio M, Sitkova Z, Schütze G, Stajić B, Stojanović D, Uhl E, Zlatanov T, Tognetti R (2020a) Evidence of elevationspecific growth changes of spruce, fir, and beech in European mixed-mountain forests during the last three centuries. Can J For Res 50(7):689-703

Pretzsch H, Grote R, Reineking B, Rötzer TH, Seifert ST (2008) Models for forest ecosystem management: a European perspective. Ann Bot 101(8):1065-1087

Pretzsch H, Rais A (2016) Wood quality in complex forests versus even-aged monocultures: review and perspectives. Wood Sci Technol 50(4):845-880

Pretzsch H, Biber P, Schütze G, Bielak K (2014a) Changes of forest stand dynamics in Europe. Facts from long-term observational plots and their relevance for forest ecology and management. For Ecol Manag 316:65-77

Pretzsch H, Biber P, Schütze G, Uhl E, Rötzer T (2014b) Forest stand growth dynamics in Central Europe have accelerated since 1870. Nature Commun 5(1):1-10 
Pretzsch H, del Río M, Biber P, Arcangeli C, Bielak K, Brang P, Ledermann T (2019) Maintenance of long-term experiments for unique insights into forest growth dynamics and trends: review and perspectives. Eur J For Res 138(1):165-185

Pretzsch H, Hilmers T, Uhl E, Bielak K, Bosela M, del Rio M, Dobor L, Forrester DI, Nagel ThA, Pach M, Avdagić A, Bellan M, Binder F, Bončina A, Bravo F, de Dios-García J, Dinca L, Drozdowski St, Giammarchi F, Hoehn M, Ibrahimspahić A, Jaworski A, Klopčič K, Kurylyak V, Lévesque M, Lombardi F, Matović B, Ordóñez C, Petráš R, Rubio-Cuadrado A, Stojanovic D, Skrzyszewski J, Stajić B, Svoboda M, Versace S, Zlatanov T, Tognetti R (2020b) European beech fagus sylvatica $L$ grows better in mixed than in monospecific stands at the edge of its distribution in mountain forests. Eur J For Res. https://doi.org/10.1007/s10342-020-01319-y

Prietzel J, Falk W, Reger B, Uhl E, Pretzsch H, Zimmermann L (2020) Half a century of Scots pine forest ecosystem monitoring reveals long-term effects of atmospheric deposition and climate change. Glob Change Biol 26(10):5796-5815

Rais A, van de Kuilen JWG, Pretzsch H (2020) Impact of species mixture on the stiffness of European beech (Fagus sylvatica L.) sawn timber. For Ecol Manag 461:117935

Rennenberg H, Seiler W, Matyssek R, Gessler A, Kreuzwieser J (2004) Die Buche (Fagus sylvatica L.) - ein waldbaum ohne zukunft im südlichen Mitteleuropa. Allg Forst-und Jagdztg 175(10-11):210-224

Schober R (1967) Buchen-ertragstafel für mäßige und starke durchforstung, In: Schober R (1972) Die rotbuche 1971. Schr forstl fak univ göttingen u niedersächs forstl versuchsanst 43/44, JD Sauerländer's Verlag, Frankfurt am Main 333

Schober R (1975) Ertragstafeln wichtiger baumarten. JD Sauerländer's Verlag, Frankfurt am Main

Sillett SC, Van Pelt R, Carroll AL, Kramer RD, Ambrose AR, Trask DA (2015a) How do tree structure and old age affect growth potential of California redwoods? Ecol Monogr 85(2):181-212

Sillett SC, Van Pelt R, Kramer RD, Carroll AL, Koch GW (2015b) Biomass and growth potential of Eucalyptus regnans up to $100 \mathrm{~m}$ tall. For Ecol Manag 348:78-91
Smith IA, Dearborn VK, Hutyra LR (2019) Live fast, die young: accelerated growth, mortality, and turnover in street trees. PLoS ONE 14(5): 0215846

Spiecker H (2000) Growth of Norway spruce (Picea abies [L.] Karst.) under changing environmental conditions in Europe. In spruce monocultures in Central Europe. Problems and prospects. EFI Proc 33:11-26

Spiecker H (2002) Tree rings and forest management in Europe. Dendrochronologia 20(1-2):191-202

Spiecker H, Mielikäinen K, Köhl M, Skovsgaard JP (eds) (2012) Growth trends in European forests: studies from 12 countries. Springer, New York

Stephenson NL, Das AJ, Condit R, Russo SE, Baker PJ, Beckman NG, Alvarez E (2014) Rate of tree carbon accumulation increases continuously with tree size. Nature 507(7490):90-93

Sterba H, Zingg A (2001) Target diameter harvesting-a strategy to convert even-aged forests. For Ecol Manag 151(1-3):95-105

VDFV (1902) Verein deutscher forstlicher versuchsanstalten, beratungen der vom vereine deutscher forstlicher versuchsanstalten eingesetzten kommission zur feststellung des neuen arbeitsplanes für durchforstungs- und lichtungsversuche. Allg Forst- und Jagdztg 78:180-184

Vuokila Y (1977) Selective thinning from above as a factor of growth and yield. Folia For 298:17

Wenk G, Antanaitis V, Šmelko Š (1990) Waldertragslehre. VEB Deutscher Landwirtschaftsverlag, Berlin, p 448

Wichmann L (2001) Annual variations in competition symmetry in even-aged Sitka spruce. Ann Bot 88(1):145-151

Zeide B (1993) Analysis of growth equations. For Sci 39(3):594-616

Zell J, Hanewinkel M, Seeling U (2004) Financial optimisation of target diameter harvest of European beech (Fagus sylvatica) considering the risk of decrease of timber quality due to red heartwood. For Policy Econ 6(6):579-593

Publisher's Note Springer Nature remains neutral with regard to jurisdictional claims in published maps and institutional affiliations. 